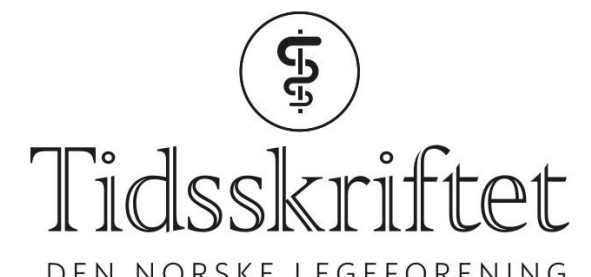

DEN NORSKE LEGEFORENING

\title{
Når det stormer på toppen
}

INTERVJU

MARTIN HOTVEDT

E-post: martin@hotvedt.no

Universitetssykehuset Nord-Norge

Da han plutselig sto på kanten av stupet i en stor konflikt, fikk Tor Ingebrigtsen bekreftet sin egen mistanke. 11 år som sykehusdirektør var nok - og litt for lenge.

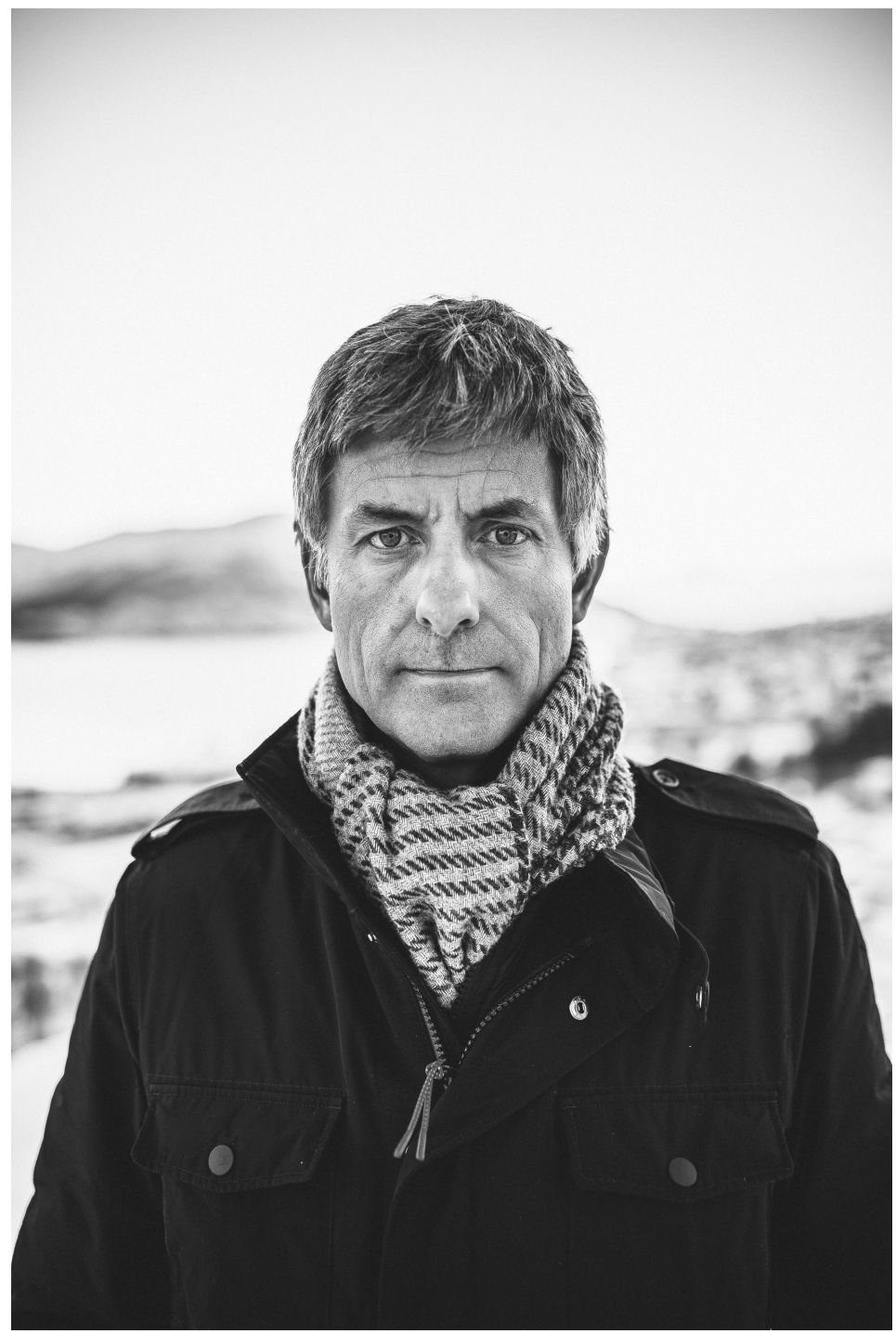

Alle foto: Marius Fiskum

- Jeg kan bli veldig alvorlig. 
Det er frost på sykkelhjelmen, og piggdekkene spraker mot januarkald tromsøasfalt. To av de tre Saab-ene han eier står på vinterlagring.

Tor Ingebrigtsen har sagt ja til å la seg portrettere i Tidsskriftet - hvis vi presser det inn etter møtet på universitetet og før klippfiskmiddagen.

Han triller sykkelen og låser den utenfor universitetskaféen mens han prøver å svare på om han har lett for å hisse seg opp.

- Jeg er ikke en type som eksploderer eller blir forbanna, men når jeg står i vanskelige saker, har jeg en tendens til å bli, ja, veldig tydelig.

Han drar litt på det.

- Alvorlig, om du vil.

Man må jo nesten stille et sånt spørsmål til en mann som etter 11 år som direktør for Universitetssykehuset Nord-Norge gikk av på grunn av en stor og dramatisk uenighet om etableringen av et PCI-senter i Bodø, en sak som etter hvert utviklet seg til å bli mye mer enn bare en faglig debatt.

Mer om det senere.

For hvordan ender egentlig en sindig orienteringsløper fra Indre Troms opp som sjef for over 6 ooo helsearbeidere?

- Mye av motivasjonen min for i det hele tatt å gå inn i medisinen stammer nok hjemmefra. Fra oppveksten, sier Ingebrigtsen.

Han er inne i kafévarmen, tar en kaffeslurk og forteller om oppveksten på Setermoen, 16 mil fra Tromsø.

- Foreldrene mine slet begge med kronisk sykdom da jeg var ung. Mamma hadde hofteslitasje og pappa senfølger etter tuberkulose. Jeg så gjennom hele oppveksten hvordan de slet med helsa og at de tidvis måtte reise sørover for å få riktig behandling.

Så kom 1970-årene og diskusjonen om opprettelsen av et universitet i Tromsø. Tor Ingebrigtsen var ung, kanskje bare 12 år, men fikk med seg det de eldre gutta snakket om i forsetet på vei til orienteringsløp i Indre Troms.

- Jeg ble nok inspirert av å høre medisinstudenten Sven Martin Almdal (senere hjertekirurg, jour.anm.) prate varmt om et universitet i Tromsø, og for meg ble det med denne bakgrunnen helt naturlig å studere medisin i Tromsø, sier han, og legger til:

- Det handlet om å bidra til at helsetjenester skal leveres likt over hele landet.

Denne grunntanken har Ingebrigtsen hatt med seg i karrieren helt siden den gang.

- Møtet med studiebyen Tromsø ble altoppslukende. Jeg var en veldig engasjert student, forklarer han, og fortsetter:

- Orientering, langrenn, studentpolitikk - alt måtte vike for medisinen.

Han ble under studietiden sammen med hun som i dag er kona. Hun var sykepleier på Nevrokirurgisk avdeling og inviterte den unge bardudølen på etterfesten til avdelingens julebord.

- Avdelingssjefen var, heldigvis for meg, i særdeles godt humør den kvelden, sier Ingebrigtsen og smiler.

- Ja, så ganske seint utpå kvelden kom det en invitasjon om å ta kontakt etter endt studie. Denne la jeg meg på sinne.

Så noen år senere, etter turnustjeneste i Narvik, banket Ingebrigtsen på den nevrokirurgiske døra, fikk innpass - og så seg ikke tilbake. 


\section{Ledet store omstillingsprosesser}

- Husker du din første lederoppgave?

Ingebrigtsen trekker på smilebåndet.

- Jeg husker i hvert fall en av de første lederaktige oppgavene mine. Som blodfersk nevrokirurg fikk jeg ansvaret for hele utstyrsutstillingen på skandinavisk nevrokirurgisk kongress i Tromsø. Dette kaoset med leverandørsamtaler og økonomistyring var hovedinntektskilden til hele kongressen. Ingebrigtsen holdt imidlertid hodet kaldt og rodde det hele i land. Avdelingssjef Jens Hugo Trumpy var meget fornøyd med sin nye disippel, og de neste årene ventet stadig flere lederoppgaver.

Ingebrigtsen hadde teft for dette.

I 2007, da Ingebrigtsen hadde noen års erfaring som sjef på nevrokirurgisk avdeling, ble det klart at den svært så populære sykehusdirektøren gjennom 23 år, folkekjære, sosiale og eksentriske Knut Schrøder, skulle gi seg.

\section{Tor Ingebrigtsen}

Født 1963

Cand.med., Universitetet i Troms $\emptyset 1988$

Turnuslege, Narvik Sykehus 1988-89

Ph.d., Universitetet i Troms $\emptyset 1998$

Direktør, Universitetssykehuset Nord-Norge 2007-18

Professor II, Universitetet i Troms $ø$ 2007-18

Professor I, Institutt for klinisk medisin, Universitetet i Troms $\emptyset$ 2019-

Overlege, Nevrokirurgisk seksjon, Universitetssykehuset Nord-Norge 2019-

«Det er ingen hemmelighet at de utfordringene Universitetssykehuset Nord-Norge står foran vil kreve en enorm innsats. Vi må finne ut hvem som skal ta tak i den voldsomme utfordringen dette krever», sa daværende styreleder Johan Petter Barlindhaug til avisa Nordlys den gang.

- Følte du på et press da du skulle ta over for en så markant direktør som Schrøder hadde vært?

- Nei, det var faktisk helt OK, svarer Ingebrigtsen raskt.

- Knut var en pådriver for min lederkarriere og en nær veileder i overgangsfasen. Vi hadde jo hatt jevnlig kontakt noen år da jeg var avdelingssjef og han var direktør.

Til tross for Schrøders kyndige veiledning og en arbeidslysten og motivert Ingebrigtsen, ble det en tøff start som direktør for en organisasjon i voldsom vekst.

- Sykehuset vokste enormt i de årene rett før jeg tok over. Det var flere sammenslåinger og områder det skulle ta ansvar for. Først kom psykiatrien, så kom ambulansetjenesten og så kom Longyearbyen sykehus inn, deretter lokalsykehusene i Narvik og Harstad, forklarer han, og fortsetter engasjert:

- Organisasjonen ble de siste årene før Knut sluttet omtrent tredoblet i størrelse. De ansatte var vant til en kort vei opp til ledelsen.

Med en eksplosiv vekst til over 6 ooo ansatte så Ingebrigtsen på det som en umulig arbeidsmåte.

- Folk var vant til å diskutere nesten alle saker med direktøren. Sånn var liksom kulturen. Beslutninger ble ikke sett på som endelige før direktøren hadde godkjent det og sagt sitt. Det var det umulig å videreføre når organisasjonen var blitt så stor. Vi måtte samle avdelingene i klinikker og opprette et nytt ledersjikt. 
Ikke alle var fornøyd med den nye direktørens lederstil.

- Mange organisatoriske nivåer var og er en utfordring fordi det oppstår et skille mellom grunnplanet og toppen. Forventningen om at jeg skulle ta stilling til enhver sak, og misnøyen med at direktøren ikke var til stede over alt, syntes jeg var vanskelig, sier han.

Likevel elsket Ingebrigtsen å lære om politiske prosesser og arbeidsmetoder.

- Kan man bli litt låst til egne meninger og idéer etter flere år som sykehusdirektør?

- Jeg tror ikke bare at det kan skje, jeg tror det er helt uunngåelig.

Han retter seg opp i ryggen og utdyper:

- Jeg tenker at man rett og slett blir lei. Selv i en direktørjobb blir det noe repetitivt over det hele, og det er slett ikke sikkert at man merker det selv. For det andre kommer man inn med et sett idéer, som ofte er gode, men med det tempoet og arbeidspresset som er i en sånn jobb, er det vanskelig å være kreativ på nytt og på nytt over så mange år. Det tredje og siste er at det oppstår en viss slitasje. Det er alltid noen saker man ikke klarer å løse. Bivirkningene drar man med seg som en gradvis større ryggsekk. På et tidspunkt må man legge den ryggsekken fra seg og la noen andre overta. Sett i ettertid satt jeg nok litt for lenge som direktør.

- Hvorfor?

- En toppleder bør generelt ikke sitte lenger enn ti år av de grunnene jeg nettopp nevnte, og det finnes det faktisk evidens for. Det ble gjeldende for meg, tenker jeg, sier han og legger til:

- Så finnes det selvsagt unntak, med Knut Schrøder som et åpenbart eksempel.

\section{Koblet til fryktkultur}

Personalsaker var det som kunne holde Ingebrigtsen våken om natta.

I de siste årene som direktør måtte Ingebrigtsen håndtere debatter om det som ble omtalt som en fryktkultur ved sykehuset. Ord som knebling, dårlig meldekultur, trusler, tilsynssaker, høyt konfliktnivå og dårlig ledelse ble brukt. En landsomfattende undersøkelse om pasientsikkerhetskultur i 2016 plasserte Universitetssykehuset NordNorge på sisteplass.

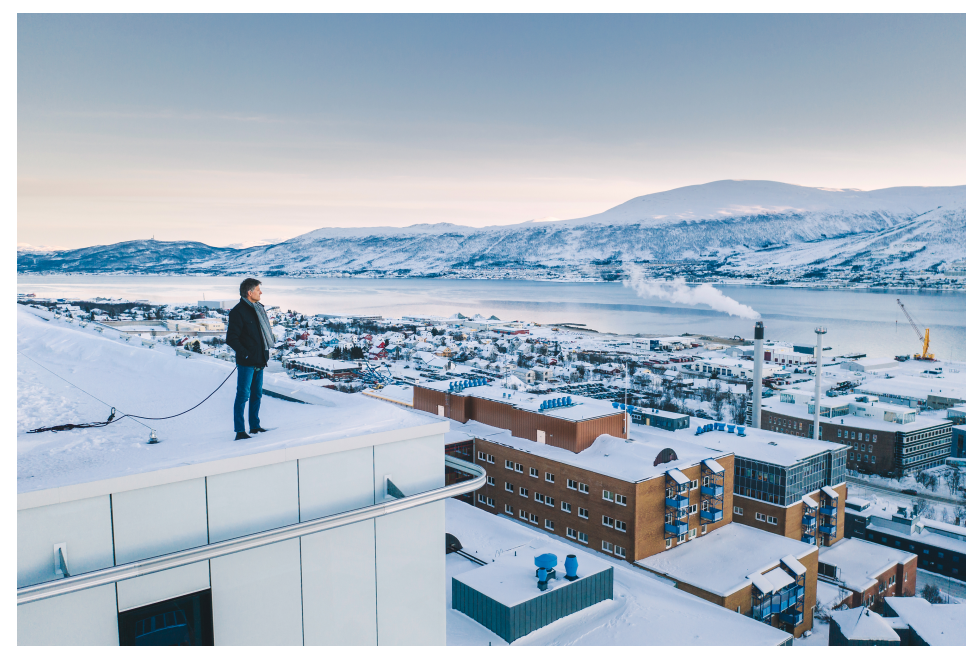

- Det var en krevende periode. Meldekulturen vår var ikke god nok.

Ingebrigtsen blir tydelig:

- Men å kalle det fryktkultur var uhensiktsmessig. Det løste jo ingen ting. Når man brukte dette begrepet, lagde man en slags definisjon på at dette ikke kunne prates om. Det i seg selv ble en stor kommunikasjonsutfordring, særlig når det handlet om personalsaker der vi som ledere har taushetsplikt.

- Hvordan var det å bli så tydelig kritisert for det noen mente var en for tøff og direkte 
lederstil?

- Det gikk ikke veldig inn på meg personlig. De som sto meg nær i denne perioden kritiserte meg faktisk for det motsatte, at jeg var for snill og ettergivende.

- Ja, noen har sagt at du kan være naiv?

- Det er nok dessverre riktig. Det er noe jeg selv synes har vært en av mine største svakheter som leder. Dette med frykt og at man knyttet det direkte til meg som toppleder, mener jeg ble brukt som et retorisk grep for å få fram et poeng.

Debatten roet seg noe fram mot 2018, og Ingebrigtsen hadde begynt å planlegge sin oppsigelse.

Han følte at hovedoppdragene han fikk da han tiltrådte, var fullført.

Lokalsykehusene i Narvik og Harstad var godt innlemmet, han hadde organisert sykehuset inn i klinikker og skapt økonomisk handlingsrom for investeringer.

Et pasienthotell til 400 millioner, et PET-senter til 500 millioner og en ny sykehusfløy til 1,6 milliarder hadde reist seg.

- Jeg var nesten helt ferdig, føler jeg. Det eneste som gjensto var åpningsseremoniene på de nye byggene og den formelle beslutningen om å bygge et nytt sykehus i Narvik. Planen var å si opp under det siste styremøtet før sommeren 2018 og så formelt gå av ved årets slutt, sier han.

Slik gikk det som kjent ikke.

\section{PCI-saken}

11. desember 2017. Det er to dager til styret i Helse Nord skal behandle det som allerede har blitt en betent sak i Nord-Norge. Spørsmålet er om man skal opprette et senter for utblokking av hjertets kransårer (PCI-senter) i Bodø. Fagmiljøet i Tromsø raser, og saken har allerede blitt utsatt flere ganger. Direktør Ingebrigtsen deler vurderingene til et samlet fagmiljø ved sitt eget sykehus og er en klar motstander av et PCI-senter i Bodø. Han mener fagmiljøet i Troms $ø$ vil svekkes og kjemper, som alltid, for regionfunksjonen til Universitetssykehuset Nord-Norge.

Han tar en telefon til daværende styreleder i Helse Nord, Marianne Telle.

Telefonsamtalen har siden blitt viden kjent.

I ettertid har man innrømmet at samtalen hadde høy temperatur.

Avisen iTroms $\emptyset$ var blant de første som skrev at Telle hevdet å ha mottatt det hun oppfattet som personlige trusler fra Ingebrigtsen. Senere fulgte oppslag i Dagens Medisin og VG. Til iTromsø sa Ingebrigtsen at han ikke hadde framsatt trusler mot Telle, men understreket samtidig at han hadde respekt for at hun oppfattet samtalen slik hun gjorde.

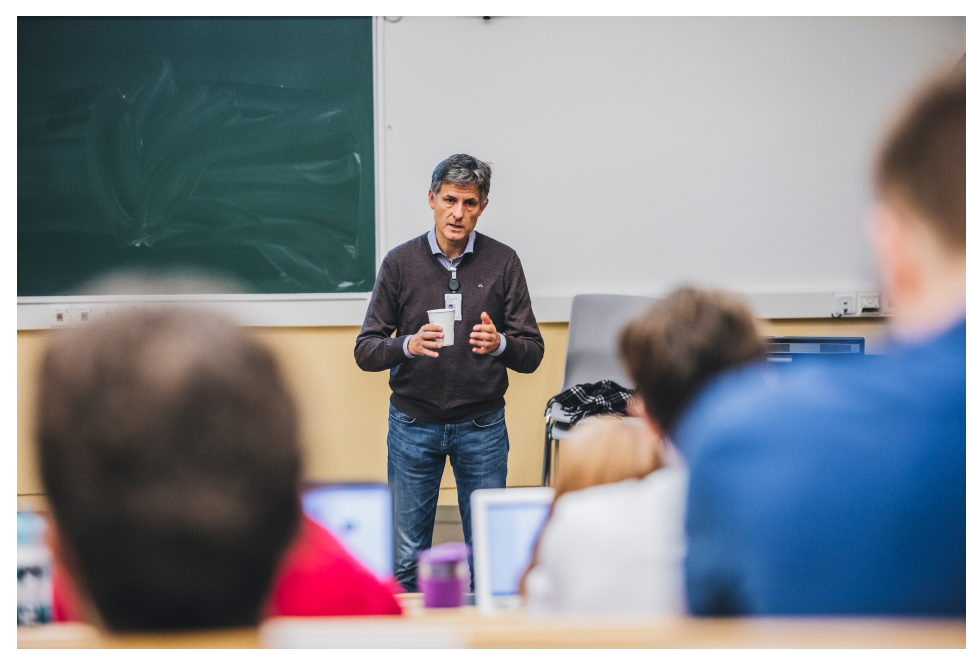

Historien ender med at Ingebrigtsen sier opp som direktør 5. februar 2018. 
- Angrer du på telefonsamtalen?

Ingebrigtsen snur seg i sofaen.

- Nei, jeg gjør ikke det.

Han åpner sykkelveska og tar fram kronikken han selv publiserte da revisorfirmaet PwC var ferdig med sin granskningsrapport av hendelsesforløpet i september 2018.

Han er nøye med å si det samme som han sa den gangen.

- For meg var det helt nødvendig og helt riktig å framføre det jeg oppfattet som et veldig viktig budskap. Og så misforsto hun meg dessverre og følte seg truet. Det var selvfølgelig aldri min mening, og det har jeg beklaget. Det jeg også har beklaget, er at formen på samtalen flyttet fokus bort fra selve saken og over på min person. Jeg oppfatter at det bidro til at det ble fattet en dårlig beslutning. I det perspektivet er jeg selvfølgelig veldig misfornøyd med den samtalen, sier han.

PwC pekte på flere lovbrudd i håndteringen av konflikten, og både daværende styreleder $\mathrm{i}$ Helse Nord, Marianne Telle, daværende styreleder ved Universitetssykehuset Nord-Norge, Jorhill Andreassen, administrerende direktør Lars Vorland i Helse Nord og Ingebrigtsen selv fikk kritikk.

Ingebrigtsen legger til:

- PwC-rapporten er et solid stykke arbeid som inneholder viktige læringspunkter for alle aktørene i saken. Den er offentlig tilgjengelig. Personlig ønsker jeg å legge saken bak meg.

- Var dette den tøffeste perioden du hadde som direktør?

- Det må man vel si, ja. Det tøffeste var perioden fram til jeg bestemte meg for å slutte. Å bli utsatt for massive anklager i media som man ikke kjenner seg igjen i, det er belastende.

- Kolleger av deg mener denne dramatiske avslutningen overskygget din 11 år lange innsats for sykehuset. Har Helse Nord takket deg av for jobben du gjorde?

- Nei.

- Hva synes du om det?

- Litt klønete.

Ingebrigtsen smiler og sier ikke mer.

- Du har gått over i en professorstilling ved Universitetet i Tromsø. Hvordan synes du Helse Nord drives i dag?

- Jeg har de siste 2-3 årene ment at universitetssykehusets regionfunksjoner for hele landsdelen ikke prioriteres høyt nok. Det arbeidet håper jeg noen andre nå overtar og fokuserer på, sier han.

\section{Mer fritid, flere veteranbiltreff}

Ingebrigtsen har satt fra seg direktørryggsekken med de tunge oppgavene.

Nå skal han forske, veilede studenter og doktorgradskandidater (noe han også gjorde som direktør) og ha litt mer fritid.

Arbeidsuka varer ikke lenger all våken tid fra søndag kveld til fredag ettermiddag.

- Jeg ser fram til mer fritid, smiler han.

Han puster litt.

- Hva gjorde du første fridag etter at den dramatiske PCI-saken hadde roet seg og du hadde sagt opp?

- Antageligvis gikk jeg på ski eller leste bilannonser på Finn.

Det er sånn han kobler av best, forklarer han. 
Ski- og hytteturer i Indre Troms med kona, eller veteranbilmekking og veteranbiltreff.

Sistnevnte drar han også kona med seg på.

- Til sommeren er det Saab-treff i Nederland. Jeg håper vi kommer oss dit, smiler han.

Det ble mange kamper for Ingebrigtsen. De fleste av dem var givende, ifølge ham selv.

- Jeg har trivdes veldig godt. Det har vært artig å forstå hele systemet, og jeg har hatt svært gode kolleger rundt meg. Man lærer hvordan samfunnet fungerer; stortinget, regjeringen og så videre. Det gir en ekstremt bred kontaktflate, fra statsminister og kronprins i den ene enden til renholdspersonell på kontoret i den andre enden, sier han, og fortsetter:

- Det jeg har satt størst pris på var å bidra til det som var min originale motivasjon til å studere medisin, nemlig å bygge et likeverdig og godt nordnorsk helsevesen - som mine foreldre ikke fikk da de var syke. Det å jobbe med å videreutvikle oss som et fullverdig universitetssykehus, samt byggeprosjektene våre, har vært svært motiverende for meg, sier han, og legger engasjert til:

- Aller mest stolt er jeg kanskje over IT-løsningen som gir pasientene tilgang til den elektroniske pasientjournalen. Min gamle sjef Jens Hugo Trumpy begynte å sende kopi av epikriser og poliklinikknotater til pasientene i 1990-årene, og Knut Schrøder innførte dette som en rutine for hele sykehuset. Det var min idé å gjøre hele pasientjournalen tilgjengelig elektronisk, og det er inspirerende å se at løsningen vi utviklet nå rulles ut i hele landet via helsenorge.no. Jeg mener at dette bemyndiger pasientene og understøtter pasientmedvirkning. Det å kunne bidra til slike framskritt har gitt glede i hverdagen, kan man si.

Av noen blir Tor Ingebrigtsen kritisert som en for tøff leder, av andre blir han hyllet som en faglig sterk mann som løftet Universitetssykehuset Nord-Norge et steg videre.

Ikke én dag angret han på at han ble direktør.

- Kan du savne direktørjobben i dag?

Han smiler.

- Nei, faktisk ikke. Jeg var veldig klar for å slutte. Det jeg har likt minst har vært rampelysfunksjonen som følger med en sånn stilling, avisoppslag, sceneopptredener, taler og bilder, sier han, og legger til:

- Det blir heldigvis ikke mange slike oppdrag lenger, humrer han og fester sikkerhetslina før en fotosesjon på kanten av et 52 meter høyt pasienthotell.

Publisert: 8. april 2019. Tidsskr Nor Legeforen. DOI: 10.4045/tidsskr.19.0147

(C) Tidsskrift for Den norske legeforening 2020. Lastet ned fra tidsskriftet.no 